\title{
Remote sensing and ground-based measurements of evapotranspiration in an extreme cold Patagonian desert
}

Cristiano $\mathrm{PM}^{\mathrm{a}^{*}}$, Pereyra DA ${ }^{\mathrm{b}}$, Bucci SJ ${ }^{\mathrm{b}}$, Madanes $\mathrm{N}^{\mathrm{a}}$, Scholz FG ${ }^{\mathrm{b}}$, Goldstein $\mathrm{G}^{\mathrm{ac}}$

a'Laboratorio de Ecología Funcional - Departamento de Ecología Genética y Evolución, Instituto IEGEBA(CONICET-UBA), Facultad de Ciencias Exactas y Naturales, Universidad de Buenos Aires, Argentina

${ }^{\mathrm{b}}$ Grupo de Estudios Biofísicos y Ecofisiológicos - Facultad de Ciencias Naturales, Universidad Nacional de la Patagonia SJB, Argentina and CONICET, Argentina

${ }^{c}$ Department of Biology, University of Miami, USA

*Corresponding author at: Facultad de Ciencias Exactas y Naturales - Universidad de Buenos Aires, Intendente Güiraldes 2160, C1428EGA, Ciudad Universitaria - Pab. II, $2^{\circ}$ Piso, CABA, Argentina. Tel.: +54 $1145763300 \times 415$.

E-mail address: piedad@ege.fcen.uba.ar (P.M. Cristiano).

Running head: Evapotranspiration in an extreme cold Patagonian desert

Total number of words: 5616

Number of tables: 1

Number of Figures: 7

Contributions of the co-authors: P.M. Cristiano contributed to the processing and analysis of remote sensing data and in the manuscript preparation. D. Pereyra was responsible of the experimental design and field measurements. S.J. Bucci and F.G. Scholz supervised the field acquisition data, field measurements data analysis and contribute to the manuscript revision. N. Madanes was involved in the analysis of remote sensing data by time series analysis. G. Goldstein helped in the experimental design of the study and in the manuscript preparation. 
Abstract Accurate estimates of seasonal evapotranspiration (ET) at different temporal and spatial scales are essential for understanding the biological and environmental determinants of ecosystem water balance in arid regions and the patterns of water utilization by the vegetation. For this purpose, remote sensing ET estimates of a Patagonian desert in Southern Argentina were verified with field measurements of soil evaporation and plant transpiration using an open top chamber. Root distribution and seasonal variation in soil volumetric water content was also analyzed. There was a high correlation between remote sensing and field measurements of ecosystem water fluxes. A substantial amount of the annual ET occurred in spring and early summer (73.4 $\mathrm{mm})$ using winter rain stored in the soil profile and resulting in water content depletion of the upper soil layers. A smaller amount of annual ET was derived from few rainfall events occurring during the mid or late summer $(41.4 \mathrm{~mm})$. According to remote sensing, the $92.9 \%$ of the mean annual precipitation returns to the atmosphere by transpiration or evaporation from the bare soil and by canopy interception. Only $7.1 \%$ infiltrates to soil layers deeper than $200 \mathrm{~cm}$ contributing to the water table recharge. Fourier time series analysis, cross-correlation methods and multiple linear regression models were used to analyze 11 years of remote sensing data to assess determinants of water fluxes. A linear model predicts well the variables that drive complex ecosystem processes such as ET. Leaf area index and air temperature were not linearly correlated to ET because of the multiple interaction among variables resulting in time lags with ET variations and thus these two variables were not included in the linear model. Soil water content, the fraction of photosynthetic active radiation and precipitation explained $86 \%$ of the ET monthly variations. The high volumetric water content and the small seasonal variations at $200 \mathrm{~cm}$ depth were probably the result of little water uptake from deeper soil horizons by roots with low hydraulic conductivity. 
Keywords: MODIS, precipitation pulses, root distribution, soil water content, temperature, water balance

Abbreviations: A, basal chamber area; ASD, air saturation deficit; D, drainage or deep percolation; ET, evapotranspiration; fPAR, fraction of photosynthetic active radiation intercepted by the vegetation; INTA, Instituto Nacional de Tecnología Agropecuarias; LAI, leaf area index; MODIS, moderate resolution imaging spectroradiometer; NDVI, normalized difference vegetation index; OTC, open top chamber;SWC50, volumetric soil water content at $50 \mathrm{~cm}$ depths; $\mathrm{T}$, transpiration; $\mathrm{T}^{\circ}$, air temperature; TSE, Transpiration and Soil Evaporation; V, volumetric flow rate: $\rho_{\text {out }}$ and $\rho_{\text {in }}$, water vapor density of outgoing and incoming air respectively.

\section{Introduction}

There are three main attributes that characterize warm arid ecosystems: (a) precipitation is so low that soil water is the dominant controlling factor for biological processes; (b) precipitation occurs in infrequent and discrete events and (c) net primary productivity is extremely low and winter temperatures are relatively mild (Noy-Meir, 1973; Lauenroth, 1979; Jobbagy and Sala, 2000; Sala et al., 2012). However, this commonly accepted characterization of desert and semi-desert ecosystems do not completely apply to dry regions where temperatures drop below freezing during several months every year, such as in the Patagonian steppe. Very low temperatures can inhibit water uptake by roots during the cold seasons and thus soil available water not only depends on precipitation but also on soil temperatures. Low soil temperature directly or indirectly increases the water flow resistance through the soil plant-atmosphere continuum (Goldstein et al., 
1985). It is well know that water uptake by roots decreases at low temperatures because of relatively high root hydraulic resistance (Ameglio, 1990), which can be attributed to low cell water permeability in roots, as well as to relatively high water viscosity (Kramer and Boyer, 1995; Bloom et al., 2004).

Evapotranspiration (ET) is an essential component of the hydrological cycle determining interactions (e.g. energy exchange) between the terrestrial ecosystems and the atmosphere (Betts et al., 1996; Weiß and Menzel, 2008; Dolman and De Jeu, 2010; Wang et al., 2010; Sun et al., 2011; Katul et al., 2012; Wang and Dickinson, 2012). Accurate estimates of seasonal ET values are of importance for understanding soil water availability and water uptake by the different plant species in a particular habitat. Evapotranspiration is a process whose regulatory mechanisms operate at different scales, from individual leaves to ecosystems. Remote sensing has emerged as a useful tool to study the spatial-temporal dynamics of ecosystem processes such as ET at large scales. The most widely used ET model was developed by Mu et al. $(2007,2011)$ using data from the MODIS-Terra sensor (MOD16A2 product). This product has been validated using 46 sites with eddy-covariance towers which are mostly located in North America (Mu et al., 2011). Currently there is no verification of this model for either warm or cold Argentina deserts neither using eddy covariance nor using open top chamber (OTC) methods. This last method, which was used in the current study, is based on the differential measurements of incoming and outgoing water vapor pressures in large chambers that can enclose several plants growing in the same site (Scholz et al., 2010). This method was developed initially to study the effects of elevated $\mathrm{CO}_{2}$ and other atmospheric gases on vegetation. It has been mainly used in ecosystems such as grasslands and scrublands since 1989 (Drake et al. 1989, Leadly and Drake 1993). 
In the Patagonian steppes, which encompass arid and semiarid ecosystems in the southern part of Argentina and Chile, the precipitation is partially intercepted by the sparse vegetation. However, most of the precipitation reaches the soil surface and it is either evaporated back to the atmosphere, enter to soil where it can be locally absorbed by roots and transpired by plants, or it is infiltrated to deeper soil layers. The topography is flat and thus runoff is negligible. One important question that we will try to answer is how much of the incoming precipitation returns to the atmosphere by transpiration and evaporation and how much is infiltrated and able to recharge deep soil layers. Another questions related to the water cycle are 1 . How much water is transpired and evaporated during the cold season if any, 2. How much water used by the vegetation during the growing season is acquired from soil water recharged during the cold season, and 3. How much is derived from rainfall pulses occurring during the summer season. Although the seasonal patterns of transpiration and bare soil evaporation have been simulated using a water-balance model developed for the Patagonian steppe (DINAQUA; Paruelo and Sala, 1995; Verón et al., 2011), these components of the water cycle have never been measured directly at ecosystem level in the Patagonian steppe despite a long history of ecosystem and ecophysiological studies (e.g. Soriano and Sala, 1983; Paruelo and Sala, 1995; Paruelo et al., 2000). The main objective of the study was to analyze the seasonal dynamic of ET at an ecosystem level in the Patagonian cold desert as a function of air and soil temperature, air saturation deficit, precipitation, soil moisture content, the fraction of photosynthetic active radiation intercepted by the vegetation (fPAR) and leaf area index (LAI) at two spatial and temporal scales using remote sensing and field measurements with an open top chamber. Toward this objective the evaluation of the MODIS ET product results for the study area, and broadly for this type of ecosystem, was performed using regression analysis between 
MODIS ET and water flux estimates obtained with the open top chamber. Individual transpiration performance of each plant species was not analyzed at this scale of study. Fourier time series analysis, cross-correlation methods and multiple linear regression models were used to statistically analyze 11 years of remote sensing continuous data comparing environmental and biological variables with ET to assess determinants of water fluxes. In addition, root distribution was studied to explain volumetric water content changes in the soil profile with depth.

\section{Materials and Methods}

\subsection{Study area}

The study area was located at the rain shadow of the Andes at $35 \mathrm{~km}$ from Río Mayo town inside the Instituto Nacional de Tecnología Agropecuaria (INTA) research station $\left(45^{\circ} 22^{\prime} 28^{\mathrm{s}} \mathrm{S} 70^{\circ} 14^{\prime} 42^{\mathrm{s}} \mathrm{W}\right)$. The vegetation is a typical Patagonian steppe dominated by grasses and evergreen and deciduous shrubs. The vegetation is sparse with a substantial percentage of bare soil. The most conspicuous shrub species are Molinum spinosum, Adesmia volckmanni, Senecio filaginoides, and the dominant grasses are Pappostipa humilis, Pappostipa speciosa, and Poa ligularis. Annual precipitations in the study area are about $150 \mathrm{~mm}$ and falls more frequently during winter (July to September) and are low and infrequent during summer (January to March). Mean annual temperature is $8.1^{\circ} \mathrm{C}$ (Paruelo et al., 1998). The area is composed of relatively elevated old fluvial deposits dissected by old inactive rivers and the few active ones carry water only during the spring season. There is a compacted soil layer between 50 $\mathrm{cm}$ and $100 \mathrm{~cm}$ depth cemented by calcium carbonate. A water table can be found at $2.55 \mathrm{~m}$ below the soil surface. 


\subsection{Soil temperature, volumetric water content and root density}

Soil temperature was determined using type $\mathrm{T}$ thermocouples installed to $10,50,100$ and $200 \mathrm{~cm}$ depth and connected to a datalogger CR10X (Campbell Scientfic). Three replicates per soil depth were used. Soil volumetric water content was monitored continuously with $\mathrm{ECH}_{2} \mathrm{O}$ probes (Decagon Devices, Inc.). The probes have an accuracy of $0.03 \mathrm{~m} \mathrm{~m}^{-1}$ and a maximum temperature sensitivity of $0.003 \mathrm{~m}^{3} \mathrm{~m}^{-3}$ per $1{ }^{\circ} \mathrm{C}$ (Decagon Devices, Inc). The probes were calibrated in the laboratory with soil samples obtained from the study site and installed in the field at 10, 50, 100 and $200 \mathrm{~cm}$ depth. They were connected to a datalogger (CR1000, Campbell Scientific).

Belowground biomass was obtained from six replicate trenches. Root density distribution was determined from $0.047 \mathrm{~m}^{3}$ soil samples, which were obtained from the sides of the trenches every $10 \mathrm{~cm}$ from the soil surface down to $200 \mathrm{~cm}$ deep. The soil samples were washed to isolate the roots from soil particles in the laboratory, and the root material was dried in an oven during $72 \mathrm{~h}$ at $80^{\circ} \mathrm{C}$.

\subsection{Soil evaporation and transpiration}

Evaporation from bare soil and transpiration from active plants were estimated using an open top chamber (OTC, Figure 1) during rainless days at about every two months from May 2010 until March 2011 (six monthly measurements during the study period). The chamber was similar to that described by Scholz et al. (2010). It consisted of a cylindrical base of $0.80 \mathrm{~m}$ diameter cone made from clear acrylic plastic and a metal frame supporting the clear plastic (Figure 1). The top of the cone had an opening (exit port) of $0.2 \mathrm{~m}$ diameter. Total chamber height was $1.66 \mathrm{~m}$ and the volume enclosed was $0.64 \mathrm{~m}^{3}$. The measurement process in chambers may modify micro-climatic conditions (Denmead et al., 1993). To minimize this effects during measurements (e.g. temperature increase), chamber measurements were as short as possible. We placed the chamber on 
micro-sites with and without plants for a very short period of time (4 min) to estimate transpiration from the vegetation and the evaporation from the soil surface, respectively. The ET measurements were done in a representative uniform steppe of $3 \mathrm{~km}^{2}$. Six replicates were obtained on grasses; six replicates were obtained on bare soil and 18 replicates on shrubs of the three dominant species at 2 to $3 \mathrm{~h}$ intervals from dawn to dusk (in average about six daily measurements) during two consecutive days in each measurement period to obtain daily values of ET. A total of 30 replicates x 6 daily measurements $\times 2$ days $\times 6$ months $=2160$ measurements were made during the study period (one year). Evapotranspiration was assumed to be negligible during the night period since there is almost no atmospheric evaporative demand and the stomata are closed (Bucci et al., 2011).

Water vapor fluxes of the vegetation and soil enclosed by the chamber $\left(0.5 \mathrm{~m}^{2}\right)$ was calculated using the difference between water vapor density of air entering and exiting the chamber. Air was pumped into the chamber using an inlet fan mounted near its base and the flow rates were measured at the exit port using a propeller anemometer. Water vapor densities of air entering and leaving the chamber were measured with a dew point hygrometer (HR 33T, YES, Yankee Environment System, Ontario, Canada). Air streams were ducted to an enclosure containing the dew point hygrometer using Beva-Line tubing at flow rates of $81 \mathrm{~min}^{-1}$ and controlled by a mass flow controller. Output from the hygrometer was recorded at $1 \mathrm{~s}$ intervals with a datalogger (CR10X, Campbell Scientific, UT, USA). The air stream to the hygrometer was switched between inflow and outflow every $2 \mathrm{~min}$. Air temperature of the out-going air stream was between 1 and $2{ }^{\circ} \mathrm{C}$ above ambient (Figure 1). Transpiration and Soil Evaporation (TSE) was calculated as:

$\mathrm{TSE}=\mathrm{V}\left(\rho_{\text {out }}-\rho_{\text {in }}\right) / \mathrm{A}$ 
were $\rho_{\text {out }}$ and $\rho_{\text {in }}$ are the water vapor densities $\left(\mathrm{g} \mathrm{m}^{-3}\right)$ of the outgoing and incoming air streams, respectively, $\mathrm{V}$ is the volumetric flow rate $\left(\mathrm{m}^{3} \mathrm{~s}^{-1}\right)$ and $\mathrm{A}$ is the basal chamber area $\left(\mathrm{m}^{2}\right)$. We removed soil evaporation value from TSE to obtain transpiration value taking into account the evaporation of sites with bare soil and the percentage of bare soil on sites with grasses or shrubs. To obtain TSE at ecosystem level, the values of soil evaporation, grass transpiration and shrub transpiration obtained with the OTC were weighted by the percentage of each component cover in the study site. To determine plant cover and to upscale ET values obtained with the OTC to ecosystem level we used 12 transects of $100 \mathrm{~m}$. Grass cover and shrub cover was estimated inside 50 x $50 \mathrm{~cm}$ frames along each transect at every $10 \mathrm{~m}$. We measured the cover of three shrub species (A. volckmannii, S. filaginoides and M. spinosum) and two grass species (P. speciosa and $P$. ligularis). The perimeter or diameter of each plant was measured within each frame. Canopy rainfall interception, which is the rainfall that is intercepted by the vegetation and evaporates directly from the leaves, is another component of evaporative fluxes. Canopy interception is highly variable in both space and time and highly dependent on the rainfall magnitude, however, there are still no estimates of this variable in the study area. According to Bradford and Lauenroth (2006), it represents on average $10 \%$ of precipitation in shrublands. This canopy interception value is comparable to canopy interception measurements in other arid and semiarid ecosystems (e.g. Návar and Bryan 1990, Dunkerley and Booth 1999, Longepierre et al. 2014). As TSE measurements with the OTC do not take into account canopy interception, it was added to field data to estimate ET at an ecosystem level to avoid under-estimation of the water vapor released to the atmosphere. For this purpose, a monthly average rainfall for the time series 2001-2011 was calculated and $10 \%$ of them were added to the field TSE measurements. It is difficult to assess the degree of uncertainty of this estimate without 
field measurements. The value of $10 \%$ may overestimate canopy interception during summer and underestimate canopy interception during the cold season however for annual budgets calculation it is considered to be a reasonable average value for the Patagonian steppe.

\subsection{Remote sensing}

Satellite images of Terra-MODIS sensor (MOD16A2 product) were used to analyze the monthly actual ET during a period of 11 years (2001-2011). The MOD16A2 product is a land surface ET product that represents all transpiration by vegetation and evaporation from understory and soil surfaces, expressed in 1-dimensional vertical units $\left(\mathrm{mm} \mathrm{d}^{-1}\right)$. The MODIS ET product has a spatial resolution of $1 \mathrm{~km}^{2}$ and a temporal resolution of 8 days. The MOD16 algorithm (Mu et al., 2007) used in this study is a revision of an algorithm proposed by Cleugh et al. (2007) based on the Penman-Monteith equation (Monteith, 1965).The MODIS ET algorithm uses global MODIS land cover, the leaf area index data (Myneni et al., 2002), albedo data (Jin et al., 2003; Salomon et al., 2006) and global surface meteorology from the Global Modeling and Assimilation Office (GMAO) meteorological data. Values of the actual daily ET estimated from MODIS (Mu et al., 2007) were corrected multiplying ET values by a factor of 0.59 for open shrublands according to $\mathrm{Mu}$ et al. (2011). Evapotranspiration values were averaged monthly to obtain average daily ET for each month. All the 8 days periods with 5 or more days falling into one particular month were included in the monthly average for that particular month. MOD15A2 and MOD13Q1 products were used to estimate the leaf area index (LAI), the fraction of photosynthetic active radiation intercepted by the vegetation (fPAR) and the normalized difference vegetation index (NDVI). Both products have $1 \mathrm{~km}$ and $250 \mathrm{~m}$ of spatial resolution and 8 and 16 days of temporal resolution, respectively. Extreme outlier data points of all MODIS products 
used were removed from the time series. Values without biophysically meaning such as negative fPAR data were also removed.

Three pixel of $1 \mathrm{~km}^{2}$ each representative of the Patagonian steppe vegetation

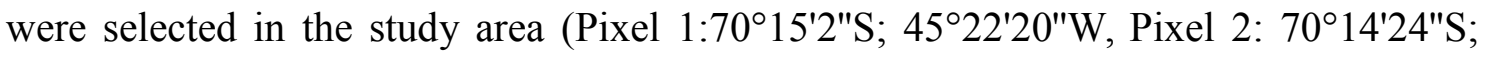
$45^{\circ} 22^{\prime} 39^{\prime \prime} \mathrm{W}$, Pixel 3: $\left.70^{\circ} 17^{\prime} 46^{\prime \prime} \mathrm{S} ; 4^{\circ} 24^{\prime} 8^{\prime \prime} \mathrm{W}\right)$. Within this area, the field measurements were performed. Values of MODIS ET, LAI, fPAR were similar across pixels and thus average values are shown hereafter. Cumulative daily rainfall values obtained from the meteorological station located in the study site (INTA experimental station Rio Mayo) were used to calculate monthly precipitation and hourly temperature values were used to obtain mean and minimum temperature monthly values.

\subsection{Statistical analysis}

A multiple regression analysis was performed between monthly average MODIS ET of the 11 years period as the dependent variable and the predictor variables were maximum air temperature, air saturation deficit (ASD), precipitation, volumetric soil water content at $50 \mathrm{~cm}$ depths (SWC50), fPAR, and NDVI. All variables were normalized prior to the regression analysis. Model selection has been carried out by the stepwise method based on $\alpha=0.05$. To evaluate the model fit, R-squared, the overall F-test, and the Root Mean Square Error (RMSE) were used. Multicollinearity was assessed by two diagnostic factors: the tolerance and the Variance Inflation Factor (VIF). The threshold values for the diagnostic factors were 0.1 and 10 , respectively. Variables with tolerance less than 0.1 and more than 10 VIF were discarded. Although the ET model developed by Mu et al. (2007) includes as input variables NDVI and LAI they did not exhibit collinearity with the dependent variable (ET) which partially justified their inclusion in the multiple regression analysis. In conjunction with meteorological data, the seasonal variations of ET were analyzed using Fourier time series analysis. Times series analysis is a powerful 
tool to explore cyclical patterns of data, allowing decomposing a complex time series into a few sine and cosine functions of particular known wavelengths. Thus it is possible to reveal a few recurring cycles of different length interval in the time series of interest (Bloomfield, 1976; Elliott and Rao, 1982; Wei, 1989). The periodogram values, which is one of the products of the time series analyses, can be interpreted in terms of the variance explained by a particular frequency (or its inverse: the time at which the recurring cycles are observed e.g., every six months, because the unit of time in this study is a month). Cross-correlations were performed between the time series of LAI/ET and Temperature/ET. The cross-correlation (von Storch and Zwiers, 1999) is a measure of similarity between two temporal patterns (e.g. LAI and ET) depicted in the cross-correlogram (cross-correlation coefficients versus time lags).

\section{Results}

There were seasonal variations in precipitation in the study site, with several precipitation events throughout the year, but the largest amount of rainfall occurred during the winter and early spring (Figure 2a). Air temperatures, as expected, were strongly seasonal with monthly minimum temperatures below $0^{\circ} \mathrm{C}$ during the cold season and close to $18^{\circ} \mathrm{C}$ during the summer (Figure $2 \mathrm{~b}$ ). The average minimum air temperatures during the study period ranged from 0 to $-8^{\circ} \mathrm{C}$, however, the absolute minimum air temperatures can drop to about $-20^{\circ} \mathrm{C}$ (Servicio Meteorológico Nacional, Argentina). MODIS evapotranspiration (ET) was well coupled to seasonal air temperature variations, with the lowest ET observed during winter and the maximum during the spring (Figure $2 \mathrm{c}$ ). Winter ET ranged between 0.1 to $0.2 \mathrm{~mm} \mathrm{day}^{-1}$. There were also small ET peaks during the late summer season which occurred in 9 out of the 11 years of continuous monthly data which can be observed as a small peak after the 
substantial ET increase during the spring season. The summer ET peak was the result of isolated summer precipitation events. Leaf area index estimated with the MODIS product was also strongly seasonal (Figure 2c). Figure 3 shows daily precipitations and monthly MODIS ET during 2009, which was selected as an example of a typical yearly ET-precipitation pattern from the 11 years of continuous monthly data. Many of the rainfall events occurred during the cold and spring seasons (June to December), however there were few isolated rainfall events in January and February (summer season). Average daily MODIS ET per month tracked the magnitude and frequency of rainfall events with the highest ET during October and a small peak ET value on February after a relatively large precipitation pulse of $14 \mathrm{~mm} \mathrm{day}^{-1}$ at beginning of February (Figure 3).

Fourier time series analysis of 11 years of average daily ET per month showed a significant peak (either maximum or minimum) every 12 months (explained variance of ET variations was $70.3 \%$ ) and a smaller significant peak at 6 months (explained variance of $16.73 \%$ ) corresponding to rainfall events during the summer. Neither LAI estimated with the MODIS product nor precipitation exhibited significant peaks (results not shown).

For each month we compared the MODIS ET estimates with the open top chamber estimates by regression analysis, a statistical procedure used for verification of the MODIS ET algorithm. Daily MODIS ET and daily transpiration and evaporation measured with the open top chamber (TSE) for May 2010-March 2011 were highly correlated and the regression line was close to the 1:1 relationship (Figure 4). MODIS ET overestimated transpirational fluxes by $14.4 \%$ in the middle of the measured ET range. For example an open top chamber value of $0.35 \mathrm{~mm}$ day $^{-1}$ corresponded to a MODIS ET value of $0.40 \mathrm{~mm} \mathrm{day}^{-1}$ (Figure 4). Neither the slope of the regression was 
significantly different from 1 nor the y-intercept was significantly different from 0 $(p<0.05)$. If the average MODIS ET values from 2001 to 2011, instead of values from May 2010-March 2011, are used in the regression analysis against the field ET estimates, the equation (MODIS ET=1.37TSE-0.08) was similar to the regression in Figure 4. This can be partially explained by the small inter-annual coefficient of annual ET variation between 2001 and 2011 which was only 4.9\%.

A multiple linear regression analysis revealed that the fPAR, the volumetric soil moisture content at $50 \mathrm{~cm}$ depth (SWC50), and precipitations explained together the 86 $\%$ of the seasonal total variations of MODIS ET (Table 1). With the exception of fPAR, which is included in the ET algorithm by MU et al. (2007) the other two variables are independent descriptors of ET (precipitation was obtained from a local meteorological station). The fPAR is an indirect input of the MODIS ET product and it is used in the multiple regression analysis as independent predictor variable, reducing to some degree the degree of correlation between the dependent (ET) and independent variables.

Average daily MODIS ET per month was linearly correlated to mean monthly air temperature when only the values during periods of high water availability were included in the linear regression $\left(\mathrm{R}^{2}=0.58\right)$ (Figure 5). Values of ET corresponding to periods of low water availability during summer were lower than values of ET obtained during periods of high water availability, at the same air temperature. Cross-time-series analysis of the 11 years showed that seasonal variations of ET were coupled to variations in LAI and $\mathrm{T}^{\circ}$. Both correlations (LAI- ET and $\mathrm{T}^{\circ}-\mathrm{ET}$ ) had the same seasonal behavior with a period of 12 months (Figure 6), however there were lags in their temporal patterns that occurred at different times. LAI had a 2 months lag with respect to $\mathrm{ET}$ while $\mathrm{T}^{\circ}$ had only one month lag with respect to $\mathrm{ET}$. 
Figure 7 shows seasonal variations in average daily MODIS ET per month calculated using the whole 2001-2011 data set. MODIS ET started to increase in August consistent with temperature increases (Figure $7 \mathrm{a}, \mathrm{b}$ ). Minimum MODIS ET was observed in June when air temperatures were very low and the highest ET occurred in October. MODIS LAI was low from April to September and relatively high during December, the beginning of the summer season in the study area (Figure 7b).

During the time period when evaporation and transpiration were measured in the field with the open top chamber, air saturation deficit varied between $0.2 \mathrm{kPa}$ (cold season) and close to $1.0 \mathrm{kPa}$ (summer, December to February) (results not shown). During winter (June to September), average monthly soil temperatures were lower at 10 cm depth $\left(1\right.$ to $\left.2{ }^{\circ} \mathrm{C}\right)$ than at deeper soil depths $\left(7\right.$ to $\left.8{ }^{\circ} \mathrm{C}\right)$ (Figure $\left.8 \mathrm{a}\right)$. There was a cross-over in soil temperature with depth from November to December, being higher at $10 \mathrm{~cm}$ and $40 \mathrm{~cm}$ depth and lower at deeper soil layers compared to the previous months. Minimum absolute daily temperatures dropped below $0{ }^{\circ} \mathrm{C}$ at $10 \mathrm{~cm}$ depth on June and July and no cross-over in soil temperatures were observed throughout the year (Inset Figure 8a). The magnitude of the soil volumetric water content variations was influenced by the soil horizon depth. At $10 \mathrm{~cm}$ depth, the water content varied strongly with a maximum in September (Figure $8 b$ ). The magnitude of the variations decreased with depth and the time of the maximum soil water content moved from September at $10 \mathrm{~cm}$ to November at $200 \mathrm{~cm}$ depth. At $200 \mathrm{~cm}$ the seasonal variations in soil water content were relatively small. The inset in Figure $8 \mathrm{~b}$ depicts the root density variations as a function of soil depth. The maximum amount of roots was observed at $10 \mathrm{~cm}$ below the soil surface and decreased exponentially with depth. Most of the roots were in the first $80 \mathrm{~cm}$ of the soil profile but roots were observed down to $200 \mathrm{~cm}$ depth. There was a decreased in root density below $70 \mathrm{~cm}$ depth consistent with the presence of a 
compacted calcium-rich soil layer (inset Figure $8 \mathrm{~b}$ ). Few roots could be observed at lower soil depths (results not shown).

\section{Discussion}

\subsection{Evapotranspiration and partitioning of water fluxes}

Evapotranspiration (ET) is a major variable involved in the study of water cycle regulation in terrestrial ecosystems and can amount to up to $95 \%$ of the incoming rainfall in dry areas (Wilcox et al., 2003). The individual components of ET at ecosystem level include evaporation from the bare soil $(\mathrm{E})$, transpiration through the plants (T) and evaporation of water intercepted by the plant canopy (I). As water limited environments currently comprise about half of the Earth's land surface (Newman et al., 2006), the pressure to use these ecosystems for agricultural and livestock grazing is expected to increase as a consequence of a rising world population and associated food demand (Yermiyahu et al., 2007). Hot and cold arid and semiarid ecosystems in Argentina span a very large continuous area extending over $3300 \mathrm{~km}$ from subtropical deserts in the northern part to very cold deserts near the southern part of the country. The two main arid ecosystems are the warm Monte desert and the cold Patagonian steppe which together represent between 55 and $60 \%$ of all terrestrial ecosystems in Argentina. Understanding regulation of water circulation pathways in water limited ecosystems is of importance for predicting changes in arid ecosystems by land use practices.

Remote sensing can assess the dynamics of ecosystem processes such as ET at large temporal and spatial scales. Algorithms are needed to transform the spectral images provided by remote sensors into values of an ecosystem process. The MODIS ET product (MOD16, Mu et al., 2007) used here can predict well the variations of 
evapotranspiration in the Patagonian steppe, overestimating ET by a relatively small percentage. The comparison between MODIS ET and field measurements was done with values of six different measurement periods comprising the whole range of environmental conditions during a year. Each data point in the regression equation was calculated by 360 open top chamber measurements for field ET estimates, and the MODIS ET estimates were obtained averaging 4 values obtained every 8 days within a month. The advantage of using remote sensors for estimating ecosystem processes such as ET after they are verified by field measurements, is the extrapolation of the ecosystem process to the entire period with remote sensing data (11 years in our case), and also allows for the comparison of seasonal and annual variations of the studied process with meteorological variables. The MODIS ET temporal dynamics in the study area had a significant 12 month period, as predicted by time series analysis, corresponding to frequent rainfall events and low temperatures during the winter, and a smaller period of 6 months corresponding to a few rain events in the middle to late summer. Most of the annual ET is lost to the atmosphere during spring and early summer which is derived from winter rain stored in the soil profile. The ET during this period (73.4 $\mathrm{mm}$ in 4 months) partially depleted the water content of the upper soil layers, indicating that winter rain stored in the soil profile is an important determinant of the annual plant's water budget in this arid ecosystem. A smaller percentage of annual ET was derived from the isolated summer rainfall events (41.4 $\mathrm{mm}$ in 3 months). During the peak of the cold season (June and July) only $11.9 \mathrm{~mm}$ were lost by ET. Low ET during the cold season can be explained by relatively low evaporative demand and low water uptake. Low rates of water acquisition can be the consequence of most shrubs being leafless during this period, low root hydraulic conductivity, as well as to the relatively high water viscosity at relatively low temperatures (e.g. Kramer and Boyer, 
1995; Bloom et al., 2004). Small rainfall events $(<5 \mathrm{~mm})$ represent less than the $20 \%$ of annual precipitation in the Patagonian steppe (Golluscio et al.,1998) and wet only the upper soil layers. These events can be utilized only by plants with a very short response time (Sala et al., 1982) and with shallow or dimorphic root systems (roots with shallow and deep roots). Bucci and coworkers (2009) observed that species-specific differences in predawn leaf water potentials of Patagonian steppe shrubs during the summer are consistent with their rooting depths. Predawn leaf water potentials, under the assumption that night time transpiration losses are very small and thus thermodynamic equilibrium is achieved at night between leaves and soil, range from $-4.0 \mathrm{MPa}$ for shallow rooted shrubs to $-1.0 \mathrm{MPa}$ for deep rooted shrubs, suggesting that deep roots species have access to abundant moisture, whereas shallow-rooted shrubs are adapted to use water deposited mainly by small rainfall events.

The correlogram in Figure 6 suggests that when environmental conditions were adequate for plant metabolic activities during the spring and early summer, the MODIS satellite data show ET increasing either one or two months earlier than temperature and LAI. At first sight it may be difficult to understand this temporal behavior. However, ET is both a biological and a physical process determined by variables such as the evaporative demand (determined by atmospheric conditions), transpiration and total leaf surface area. The time series of ET and temperature were strongly correlated with only a difference of one month lag in their seasonal patterns. Evapotranspiration increases at the beginning of the growing season when evaporative demand increases due to rising air temperatures and high soil water content in the upper soil layers in winter. During the summer, soil water content in the upper soil layers is lowest thus limiting ET during this season. Plant growth is a relatively slow process which depends on high irradiance and adequate soil water content and consequently LAI peaked two month after 
maximum ET as shown by the correlogram. A similar temporal cross-correlations approach was used to test the relationship between MODIS derived vegetation water content indices and vegetation water content measured in the field in a Mediterranean shrubland (Delenne et al., 2013). In this Mediterranean shrubland study, the MODIS signal increase a few days after increasing the soil volumetric water content.

The mean annual rainfall for the period 2010-2011 was $145.5 \mathrm{~mm}$ and the MODIS ET corrected by equation in Figure 4 (relationship between field and MODIS ET values) was $135.1 \mathrm{~mm}$. This means that $92.9 \%$ of the mean annual precipitation returns to the atmosphere through ET. According to these calculations, only $7.1 \%$ of the annual precipitation infiltrates to soil layers deeper than $200 \mathrm{~cm}$ (drainage or deep percolation). The mean annual rainfall for the 12 month period of 2010-2011 during the OTC measurements was $127 \mathrm{~mm}$. The annual evaporation from bare soil was $49.7 \mathrm{~mm} \mathrm{y}^{-1}$ and annual transpiration from grasses and shrubs was $54.4 \mathrm{~mm} \mathrm{y}^{-1}$ (annual ET $109.1 \mathrm{~mm} \mathrm{y}^{-1}$ ) during this period (data not shown). This annual ET represents $85.9 \%$ of annual rainfall; the remaining $14.1 \%$ can be accounted by canopy interception and deep percolation. Notice the close agreement between remote sensing ET and field measurements ET data. The soil water simulation model by Paruelo and coworkers (2000) in a site with $150 \mathrm{~mm}$ annual precipitation, predicted that deep percolation is about $7 \%$, slightly higher than the value obtained in this study with field ET measurements (4.1\%) and similar to ET estimated by remote sensing (7.1\%). Our estimates of deep percolation with field measurements will depend on the annual values of canopy interception used that we assumed to be $10 \%$, and thus being an average value for the 12 month period does not depend on the amount and intensity of each individual rain event.

\subsection{Environmental and biological determinants of Evapotranspiration}


The volumetric soil water content at $50 \mathrm{~cm}$ depth, the fraction of photosynthetic active radiation and precipitation explained together $86 \%$ of the total variations of ET MODIS according to the multiple linear regression analysis $\left(\mathrm{R}^{2}=0.86\right)$. Leaf area index and air temperature were not linearly correlated with ET because of the multiple interaction among variables resulting in time lags. For example, air temperature and ASD increase at the beginning of the growing season but low soil temperature results in soil water unavailability for plant water use and many deciduous shrubs species are still either leafless or the leaves are still expanding. It is possible that these two variables (ASD and air temperature) were not included in the linear model due to temporal lag effects.

The seasonal changes in soil water content at different depths were influenced in this study by the pattern of distribution of roots and soil temperatures. Root abundance decreased exponentially with depth and a relatively small amount of roots can be observed below $70 \mathrm{~cm}$ depth. At 10 and $50 \mathrm{~cm}$ depths the seasonal changes in soil available water were substantially larger than those at $200 \mathrm{~cm}$ suggesting that roots utilize a substantial amount of water within the upper portion of the soil profile. During the summer (January to March) when evaporative demand is high and precipitation is very low, the soil water content increased with depth because there are only few roots at deeper soil layers. During the winter, contrary to water content differences across the soil profile measured during the summer, the volumetric water content at $10 \mathrm{~cm}$ was substantially higher than at deeper soil layers. It is possible that the low winter soil temperatures of the upper soil layers restrict water uptake resulting in higher water content at $10 \mathrm{~cm}$ depth compared to soil water content at lower soil depths, and that furthermore the evaporation from bare soil is very low. A very low LAI and air saturation deficit put a ceiling on the amount of water that is transpired during the winter. There is only one evergreen shrub with relatively high cover (Senecio spp.) in 
the study site, and the grasses have very few potentially active green leaves during the cold period. According to the MM5 model developed by the CIMA (Centro de Investigación del Mar y de la Atmósfera, CONICET-UBA, Argentina), a substantial increase in air temperature is expected to occur in central Patagonia due to global warming (e.g. an increase of $1.5^{\circ} \mathrm{C}$ is predicted to occur during the $2050 / 2059$ years). During the same period, there will be no increases in precipitation according to the same model. This may have consequences for the hydrological cycle and species composition of the vegetation in the study area. High temperatures may decrease the magnitude of the winter water recharge in the soil and increase ET during the growing season, mainly as a result of high soil evaporation and transpiration. This will reduce the amount of water available in the upper soil layer perhaps resulting in a decrease in the abundance of the more shallow rooted plants (e.g. grasses).

As indicated before, only $4.4 \%$ of total annual precipitation infiltrates down to $200 \mathrm{~cm}$ in the soil profile. Species with deep roots exploring dependable soil water sources (small or negligible seasonal water content variations) such as Schinus johnstonii and Berberis heterophylla have low specific hydraulic conductivity compared to species with shallow root systems such as Senecio filaginoides and Mulinum spinosum (Bucci et al. 2009; 2013). Shallow rooted shrub species with high hydraulic conductivity and grasses are plants that may efficiently utilize soil water during the small summer rainfall pulses and which are accountable for the summer increases in ET observed with remote sensing. Other explanation for the relatively constant soil water content at $200 \mathrm{~cm}$ depth may be related to the presence of a water table at about $2.5 \mathrm{~m}$ depth which could result in non-saturated water flow during the summer, when the soil water potential gradient is favorable for upward water movement. 


\section{Conclusions}

The results of this study show that the MODIS ET product (MOD16) results were consistent with field measurements of ET by the open top chamber method. The soil water content, the fraction of photosynthetic active radiation, and precipitation can predict $86 \%$ of the ET monthly variations in a central Patagonia cold desert. The linear model predicts well the variables that drive complex ecosystem processes such as ET. Leaf Area Index and air temperature were not linearly correlated to ET because of the multiple interactions among variables resulting in time lags. Evapotranspiration increases one to two months earlier than temperature and LAI during the spring, when environmental conditions start to be adequate for plant metabolic activities. The high volumetric water content and the small seasonal variations at $200 \mathrm{~cm}$ depth were probably the result of relatively small water uptake by plants in the deeper soil horizons and perhaps from non saturated upward water transport from the water table. Most of the annual ET occurred in spring and early summer indicating that winter rain stored in the soil profile is an important determinant of the seasonal pattern of the water cycle in this arid ecosystem. A relatively small percentage of annual ET was derived from few rainfall events occurring during the mid or late summer. The $95.6 \%$ of the mean annual precipitation returns to the atmosphere by transpiration or evaporation from the bare soil and by canopy interception. Leaks from the ecosystem water cycle are from bare soil evaporation and from a small amount of deep percolation. The high correlation between remote sensing and field measurements of ecosystem water fluxes will help the investigation of the regional hydrological balance at different temporal and spatial scales across the Patagonian steppe.

\section{Funding}


This work was partially supported by ANPCyT-FONCyT through PICT projects (20081202; 2010-0960; 2012-2344) and a doctoral fellowship to D. Pereyra.

\section{Acknowledgements}

We thank the Instituto de Clima y Agua of INTA Castelar for providing satellite images and particularly Patricio Oricchio for his ongoing advice.

\section{References}

Ameglio T, Morizet J, Cruiziat P, Martignac M.1990.The effect of root temperature on water flux, potential and root resistance in sunflower. Agronomie 10: 331-340.

Betts AK, Ball JH, Beljaars ACM, Miller MJ, Viterbo PA. 1996. The land surfaceatmosphere interaction: A review based on observational and global modeling perspectives. J. Geophys. Res. 101: 7209-7225.

Bloom AJ, Zwieniecki MA, Passioura JB, Randall LB, Holbrook NM, St. Clair DA. 2004. Water relations under root chilling in a sensitive and tolerant tomato species. Plant Cell Environ. 24: 971-979.

Bloomfield P. 1976. Fourier Analysis of Time Series: An Introduction, 2nd ed. Wiley: New York; 257 pp.

Bradford JB, Lauenroth WK. 2006. Controls over invasion of Bromus tectorum: The importance of climate, soil, disturbance and seed availability. J. Veg. Sci. 17: 693704.

Bucci SJ, Scholz FG, Goldstein G, Meinzer FC. 2009. Soil water availability as determinant of the hydraulic architecture in Patagonian woody species. Oecologia 160: $631-641$. 
Bucci SJ, Scholz FG, Iogna PA, Goldstein G. 2011. Economía de agua de especies arbustivas de la Estepa Patagónica. Ecología Austral 21(1): 43-60.

Bucci SJ, Scholz FG, Peschiutta ML, Arias NS, Meinzer FC, Goldstein G. 2013.The stem xylem of Patagonian shrubs operates far from the point of catastrophic dysfunction and is additionally protected from drought-induced embolism by leaves and roots. Plant Cell Environ. 36: 2163-2174.

Centro de Investigación del Mar y de la Atmósfera-CIMA- CONICET-UBA, Argentina (2015). Cambios climáticos en la Región Patagonia, Antártida e Islas del Atlántico Sur. In: Cambio climático en Argentina; tendencias y proyecciones. Proyecto Tercera Comunicación Nacional a la CMNUCC de la Secretaria de Ambiente y Desarrollo Sustentable de la Nación (SAyDS): CABA; 280-341 pp.

Cleugh HA, Leuning R, Mu Q, Running SW. 2007. Regional evaporation estimates from flux tower and MODIS satellite data. Remote Sens. Environ. 106(3): 285-304.

Delenne C, Bailly J-S, Deshayes M. 2013. Testing the relevance of daily MODIS data to monitor mediterranean shrubland canopy water content with temporal crosscorrelation analyses. Int. J.Agr. Environ. Inform. Syst. 4(1): 1-19.

Denmead OT, Dunin FX, Wong SC, Greenwood EAN. 1993. Measuring water use efficiency of Eucalypt trees with chambers and micrometeorological techniques. $J$. Hydrol. 150: 649-664.

Dolman AJ, De Jeu RAM. 2010. Evaporation in focus. Nat. Geosci. 3: 296.

Elliott DF, Rao KR. 1982. Fast Transforms: Algorithms, Analyses, Applications. Academic Press: New York; 448 pp.

Drake BG, Leadley PW, Arp WJ, Nassiry D, Curtis PS. 1989. An open top chamber for field studies of elevated atmospheric $\mathrm{CO} 2$ concentration on saltmarsh vegetation. Funct. Ecol. 3: 363-371. 
Dunkerley DL, Booth TL. 1999. Plant canopy interception of rainfall and its significance in a banded landscape, arid western New South Wales, Australia. Water Resour. Res. 35 (5): 1581-1586

Goldstein GH, Brubaker LB, Hinckley TM. 1985. Water relations of white spruce (Piceaglauca (Moench) Voss) at tree line in north central Alaska. Can. J. For. Res. 15(6): 1080-1087.

Golluscio RA, Sala OE, Lauenroth WK. 1998. Differential use of large summer rainfall events by shrubs and grasses: a manipulative experiment in the Patagonian steppe. Oecologia 115: 17-25.

Jin Y, Schaaf CB, Gao F, Li X, Strahler AH, Lucht W, Liang S. 2003.Consistency of MODIS surface bidirectional reflectance distribution function and albedo retrievals: 1. Algorithm performance. J. Geophys. Res. 108: 4158-4170.

Jobbagy EG, Sala OE. 2000. Controls of grass and shrub aboveground production in the Patagonian steppe. Ecol. Appl.10: 541-549.

Kramer PJ, Boyer JS. 1995. Water Relations of Plants and Soils. Academic Press: New York; 495 pp.

Lauenroth WK. 1979. Grassland primary production: North American Grasslands in perspective. In: Perspectives in Grassland Ecology. Ecological Studies, French NR (ed). Springer: Heidelberg; 3-24.

Leadley PW, Drake BG. 1993. Open top chambers for exposing plant canopies to elevated $\mathrm{CO} 2$ concentration and for measuring net gas exchange. Plant Ecol. 104105: $3-15$.

Longepierre D, Mouillot F, Ouelhazi B, Ourcival JM, Alain Rocheteau, Degueldre D. 2014. True water constraint under a rainfall interception experiment in a 
Mediterranean shrubland (Northern Tunisia): confronting discrete measurements with a plant-soil water budget model. Plant Ecology, Springer Verlag; 33 pp.

Monteith JL. 1965. Evaporation and environment. Symp. Soc. Exp. Biol. 19: 205-234.

$\mathrm{Mu}$ Q, Heinsch F, Zhao M, Running S. 2007. Development of a global evapotranspiration algorithm based on MODIS and global meteorology data. Remote Sens. Environ. 111 (4): 519-536.

Mu Q, Zhao M, Running SW. 2011. Improvements to a MODIS global terrestrial evapotranspiration algorithm. Remote Sens. Environ. 115: 1781-1800.

Myneni RB, Knyazikhin Y, Privette JL, Glassy J, Tian Y, Wang Y, Hoffman S, Song X, Zhang Y, Smith GR, Lotsch A, Friedl M, Morisette JT, Votava P, Nemani RR, Running SW. 2002. Global products of vegetation leaf area and fraction of absorbed PAR from year one of MODIS data. Remote Sens. Environ. 83: 214-231.

Navar J, Bryan R. 1990. Interception loss and rainfall redistribution by three semi-arid growing shrubs in northeastern Mexico. J. Hydrol. 115: 51-63. Newman BD, Wilcox BP, Archer SR, Breshears DD, Dahm CN, Duffy CJ, McDowell NG, Phillips FM, Scanlon BR, Vivoni ER. 2006. Ecohydrology of water-limited environments-a scientific vision. Water Resour. Res. 42: 1-15.

Noy-Meir I. 1973. Desert Ecosystems: Environment and Producers. Annu. Rev. Ecol. Syst. 4: 25-51.

Paruelo JM, Sala OE. 1995. Water losses in the Patagonian steppe: a modelling approach. Ecology 76(2): 510-520.

Paruelo JM, Beltran A, Jobaggy E, Sala OE, Golluscio RA. 1998. The climate of Patagonia: general patterns and controls on biotic processes. Ecología Austral 8: 85101. 
Paruelo JM, Sala OE, Beltran AB. 2000. Long-term dynamics of water and carbon in semi-arid ecosystems: a gradient analysis in the Patagonian steppe. Plant Ecol. 150: $133-143$.

Sala OE, Lauenroth WK, Parton WJ. 1982. Plant recovery following prolonged drought in a shortgrass steppe. Agric. Meteorol. 27: 49-58.

Sala OE, Gherardi LA, Reichmann L, Jobbágy E, Peters D. 2012. Legacies of precipitation fluctuations on primary production: theory and data synthesis. Philos. T. Roy. Soc. B 367(1606): 3135-3144.

Salomon J, Schaaf C, Strahler A, Gao F, Jin Y. 2006. Validation of the MODIS bidirectional reflectance distribution function and albedo retrievals using combined observations from the aqua and terra platforms. IEEE Trans. Geosci. Remote Sens. 44 (6): 1555-1565.

Scholz FG, Bucci SJ, Hoffmann WA, Meinzer FC, Goldstein G. 2010. Hydraulic lift in a Neotropical savanna: Experimental manipulation and model simulations. Agric. For. Meteorol.150: 629-639.

Soriano A, Sala OE. 1983. Ecological strategies in a Patagonian arid steppe. Vegetatio 56: $9-5$.

Sun G, Alstad K, Chen J, Chen S, Ford CR, Lin G, Liu C, Lu N, McNulty SG, Miao H. 2011. A general predictive model for estimating monthly ecosystem evapotranspiration. Ecohydrol. 4(2): 245-255.

Verón SR, Paruelo JM, Oesterheld M. 2011.Grazing-induced losses of biodiversity affect the transpiration of an arid ecosystem. Oecologia 165(2): 501-510.

vonStorch H, Zwiers F. 1999. Statistical Analysis in Climate Research. Cambridge University Press: New York; 494 pp. 
Wang L, Caylor KK, Villegas JC, Barron-Gafford GA, Breshears DD, Huxman TE, 2010. Partitioning evapotranspiration across gradients of woody plant cover: Assessment of a stable isotope technique. Geophys. Res. Lett. 37: 1-7.

Wang K, Dickinson RE. 2012. A review of global terrestrial evapotranspiration: Observation, modeling, climatology, and climatic variability. Rev. Geophys. 50: 154.

Wei WW. 1989. Time Series Analysis: Univariate and Multivariate Methods. AddisonWesley: New York; 614 pp.

Weiß M, Menzel L. 2008. A global comparison of four potential evapotranspiration equations and their relevance to stream flow modelling in semi-arid environments. Adv. Geosci. 18: 15-23.

Wilcox BP, Breshears DD, Allen CD. 2003. Ecohydrology of a resource-conserving semiarid woodland: effects of scale and disturbance. Ecol. Monog. 73: 223-239.

Yermiyahu U, Tal A, Ben-Gal A, Bar-Tal A, Tarchitzky J, Lahav O. 2007. Rethinking desalinated water quality and agriculture. Science 318: 920-921. 
Table 1: Coefficients, standard error (SE), $p$ values of variables ( $p$ value), variance inflation factor (VIF), determinant coefficient $\left(\mathrm{R}^{2}\right)$, Fisher statistical $(F)$, degree of freedom (gl) and model $\mathrm{p}$ value (p) of a multiple linear regression analysis using monthly MODIS evapotranspiration as the dependent variable. ASD is the air saturation deficit, fPAR is the fraction of photosynthetic active radiation intercepted by vegetation, $\mathrm{pp}$ is precipitations, $\operatorname{maxT}^{\circ}$ is maximum temperature, NDVI is the normalized difference vegetation index and SWC50 is the soil water content at $50 \mathrm{~cm}$ depth. Variables were previously normalized. Model 1 depicts all variables included in the linear regression analysis while model 2 shows the final model proposed to predict evapotranspiration with $\alpha=0.05$. NDVI was included in the model because was marginally significant but increase the $\mathrm{R}^{2}$ of the overall model from 0.86 to 0.91 .

\begin{tabular}{clcccccc}
\hline $\begin{array}{c}\text { Mode } \\
\mathbf{l}\end{array}$ & Variables & $\begin{array}{c}\text { Coefficien } \\
\mathbf{t}\end{array}$ & $\mathbf{S E}$ & $\mathbf{p ~ v a l u e}$ & $\mathbf{V I F}$ & $\mathbf{R}^{2}$ & $\boldsymbol{F} ; \mathbf{g l}_{\mathbf{t}} ; \mathbf{p}$ \\
\hline \multirow{6}{*}{1} & ASD (kPa) & -0.871 & 0.526 & 0.159 & 44.6 & & \\
& fPAR (\%) & -0.656 & 0.148 & 0.007 & 3.5 & & \\
& pp (mm) & -0.5 & 0.144 & 0.018 & 3.3 & & \\
& maxT $^{\circ}\left({ }^{\circ} \mathrm{C}\right)$ & 0.609 & 0.556 & 0.324 & 49.9 & 0.93 & $26.01 ; 11 ; 0.001$ \\
& NDVI & 0.398 & 0.119 & 0.021 & 2.3 & & \\
& SWC50 (\%) & 0.410 & 0.085 & 0.005 & 2.5 & & \\
& Constant & 0.130 & 0.08 & 0.165 & - & & \\
\hline \multirow{2}{*}{2} & fPAR (\%) & -0.634 & 0.114 & 0.001 & 1.0 & & \\
& pp (mm) & -0.478 & 0.113 & 0.003 & 1.0 & 0.86 & $23.45 ; 11 ;<0.001$ \\
& SWC50 (\%) & 0.298 & 0.078 & 0.005 & 1.0 & & \\
\hline & Constant & 0.094 & 0.111 & 0.419 & - & & \\
\hline
\end{tabular}


Figures and legends

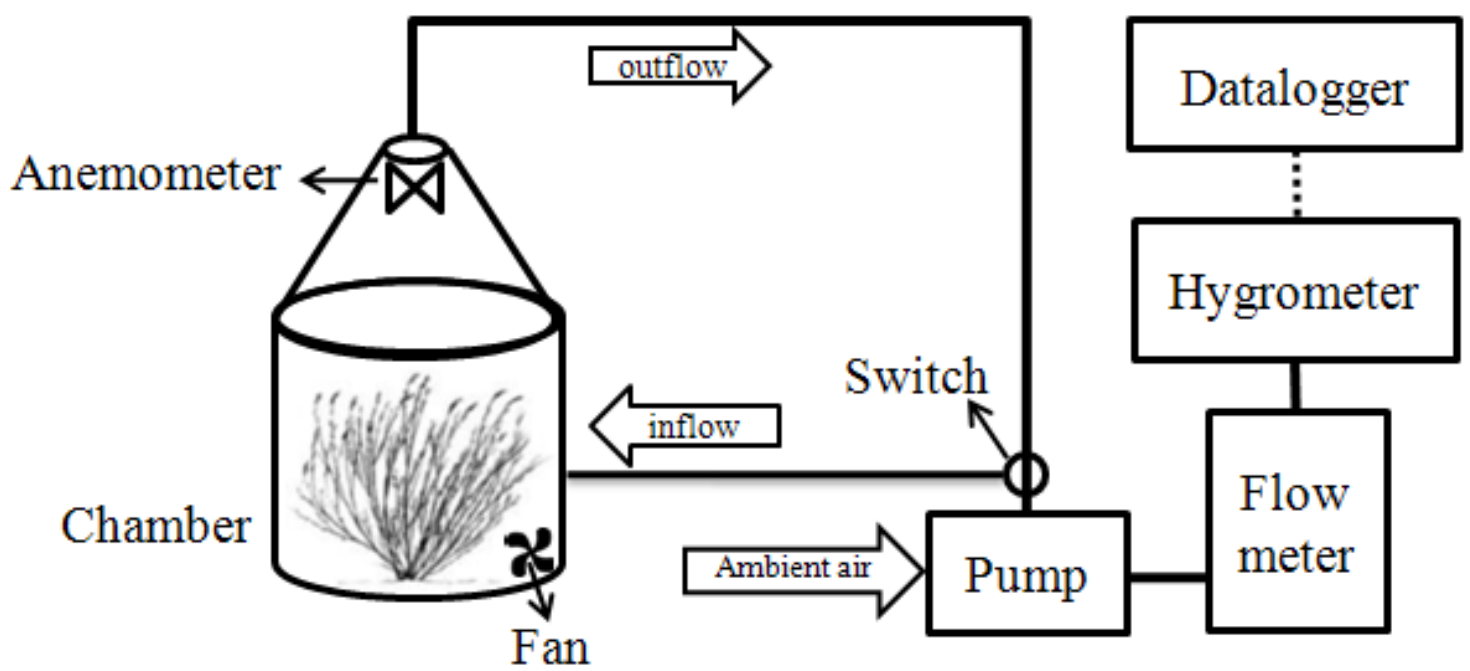

Figure 1: Scheme of the Open Top Chamber used in field measurements. The components of the system are: (a) chamber, (b) pump, (c) dew point hygrometer, (d) mass flow meter, (e) anemometer, (f) internal recirculation fan and (g) datalogger. Continuous lines are parts of the pneumatic system while the dashed line is a cable connector. 


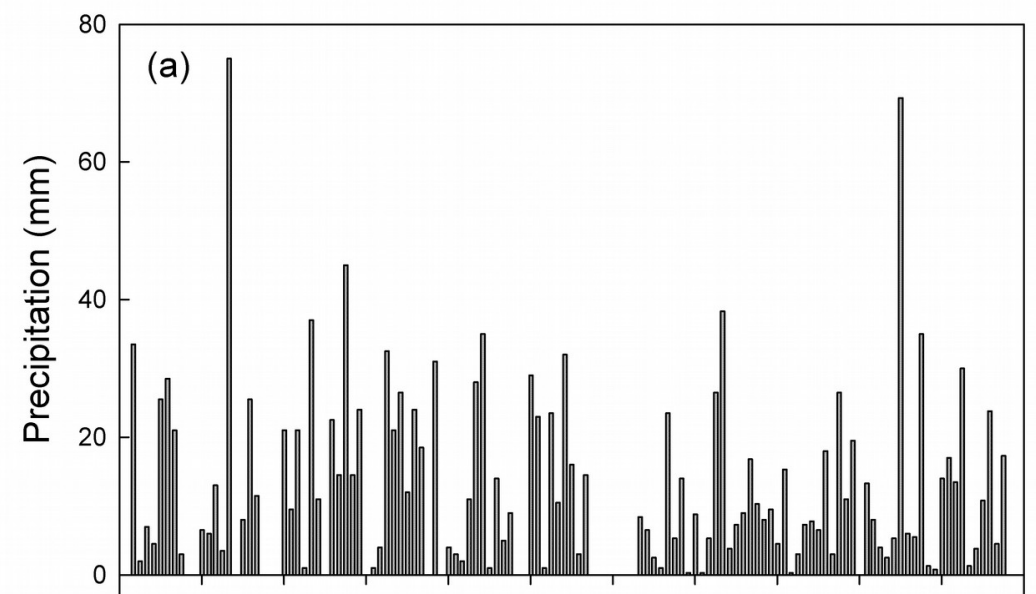

(b)
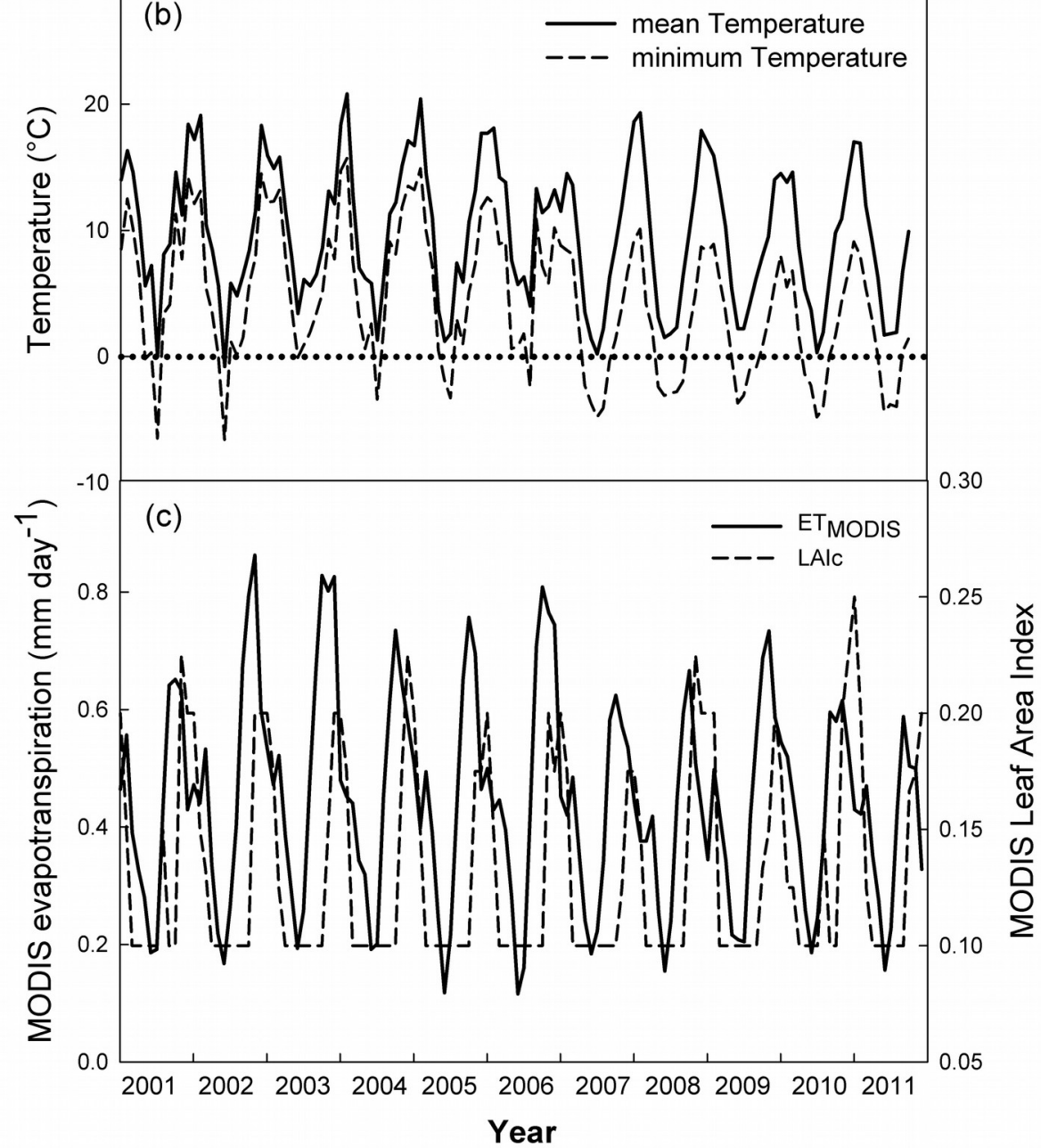

Figure 2: Seasonal variations of (a) total monthly precipitation, (b) average monthly minimum and monthly mean air temperatures from 2001 until 2011 (Meteorological data provided by INTA Meteorological Station, Argentina) and (c) average daily evapotranspiration per month and leaf area index obtained from the MODIS product for the same time period. 


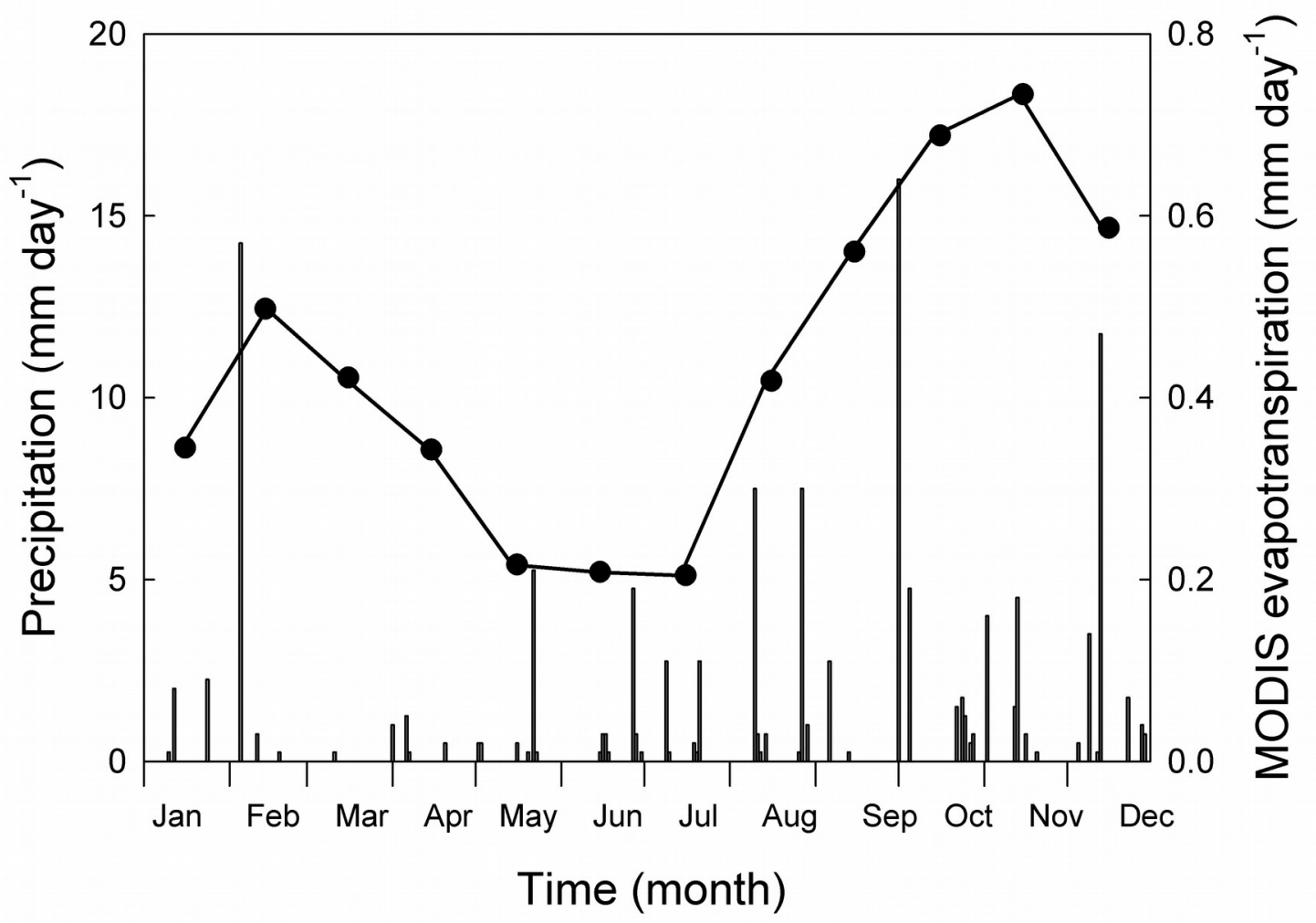

Figure 3: Variation in daily precipitations (vertical lines) and average daily MODIS evapotranspiration (filled symbols connected by a continuous line) per month from January to December 2009. 


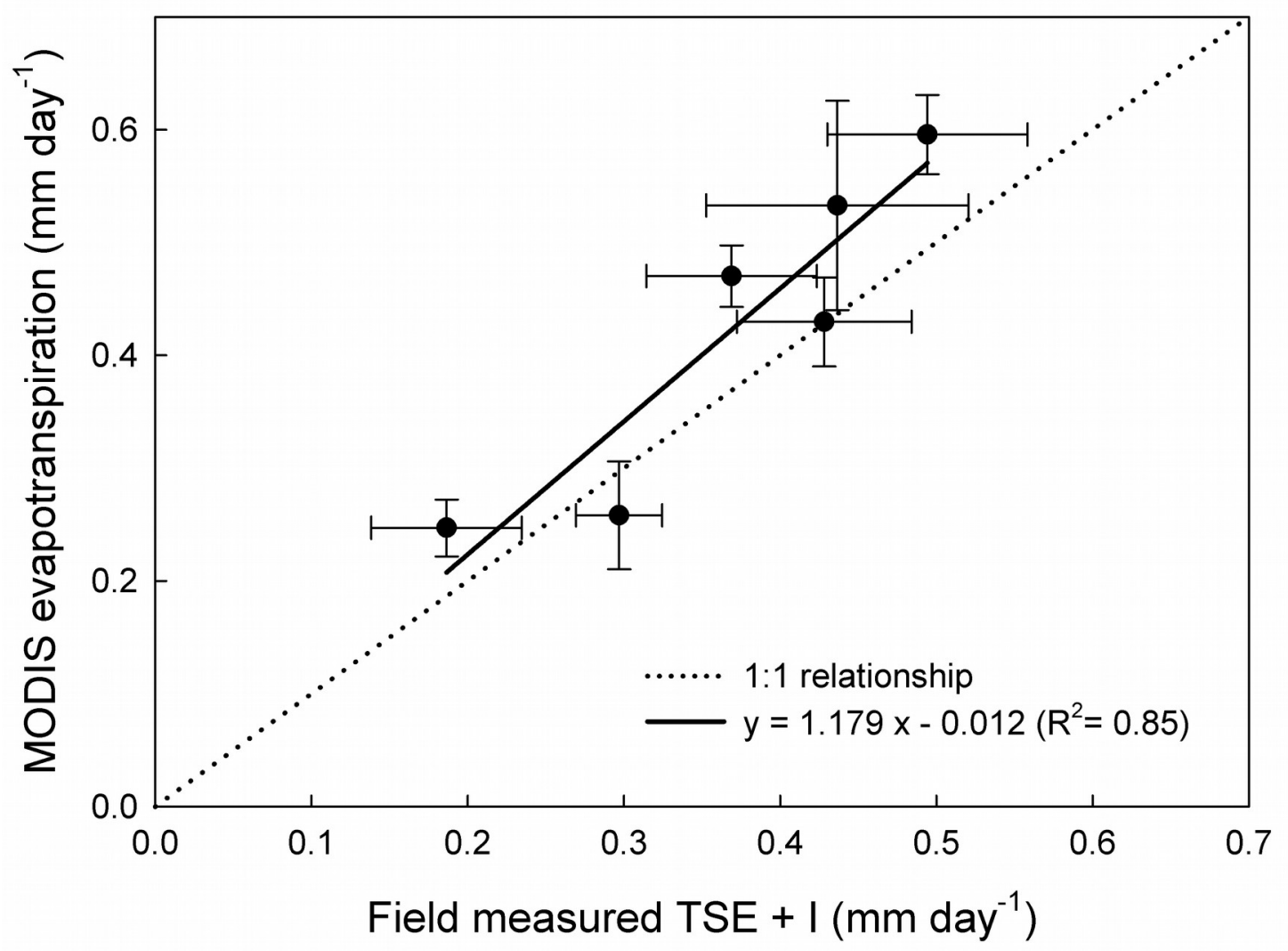

Figure 4: Linear relationship between Transpiration and Soil Evaporation (TSE) measured in the field with an open top chamber plus canopy interception (I) (field measured TSE + I) and MODIS evapotranspiration for the same six months covering one year from May 2010 to March 2011. The linear regression equations and the $\mathrm{R}^{2}$ value are indicated in the graph. Both Y-intercepts and slope were no significant different from zero and one, respectively $(\mathrm{p}<0.05)$. The 1:1 relationship is indicated as a dotted line. Symbols are means \pm SE. 


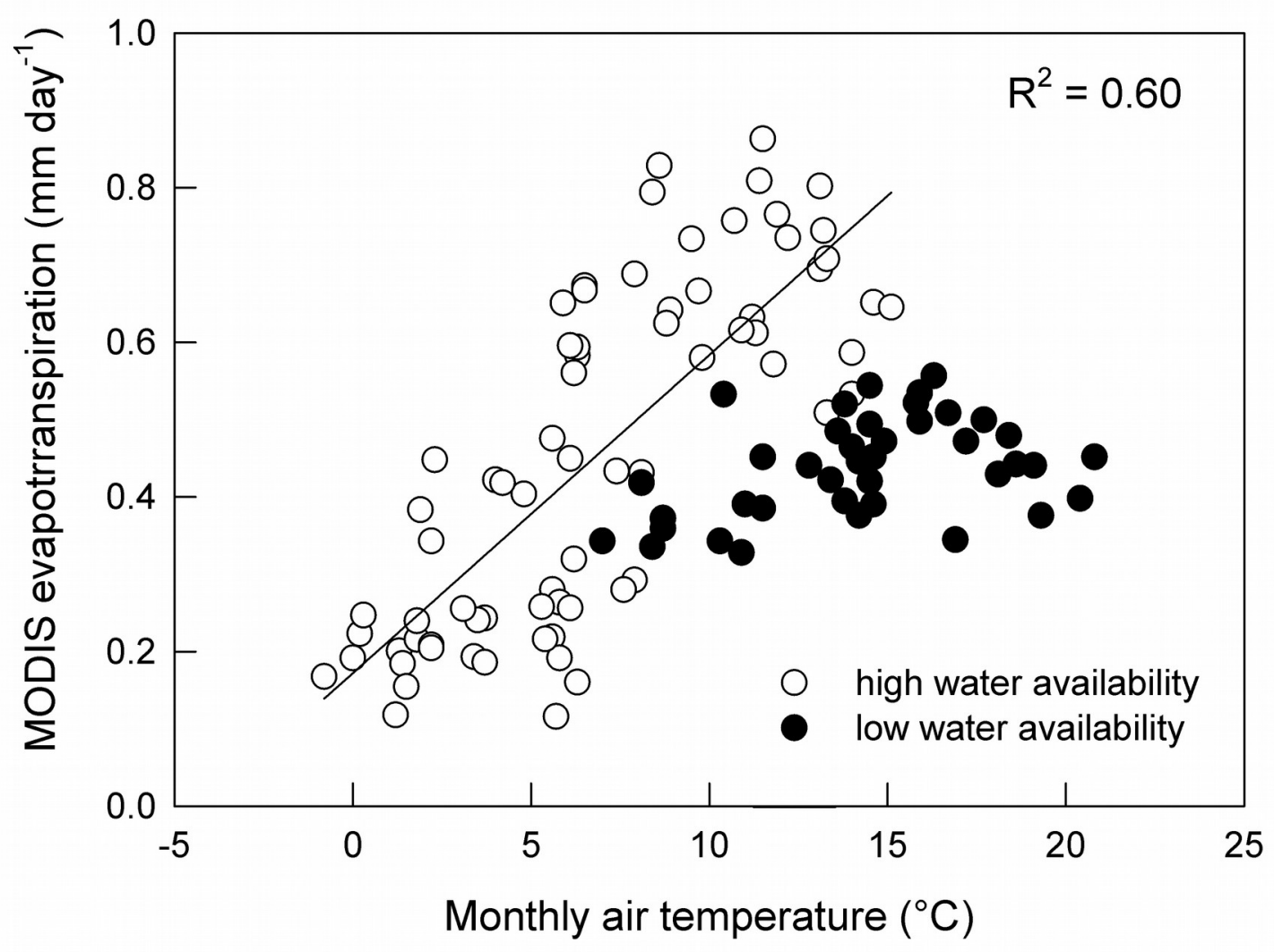

Figure 5: Relationship between average daily MODIS evapotranspiration per month and mean monthly air temperature from January 2001 to December 2011. From June to August water can be frozen in the upper soil layers. Filled symbols represent months with low soil water availability during the summer (January to April). Open symbols represent months with high soil water availability (May to December). The line is the linear regression fitted to the months with high soil water availability. The linear regression is MODIS ET $=0.04$ mean $\mathrm{T}+0.17$. 


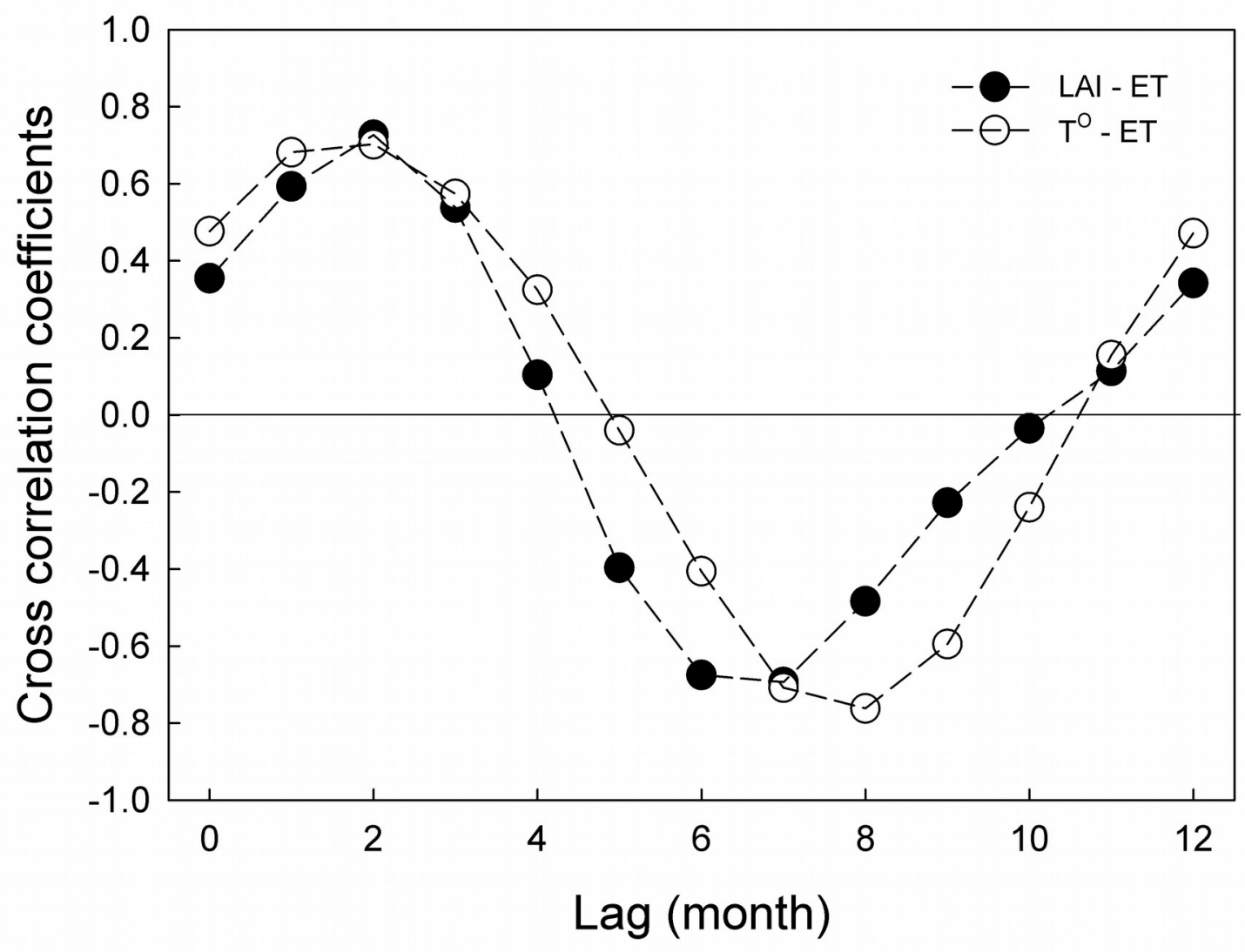

Figure 6: Cross correlation coefficients between MODIS mean monthly Leaf Area Index (LAI) and MODIS evapotranspiration (ET) (filled symbols), and cross correlation coefficients between mean monthly Temperature $\left(\mathrm{T}^{\circ}\right)$ and average daily MODIS evapotranspiration per month (ET) (open symbols) as a function of time lags in months. 


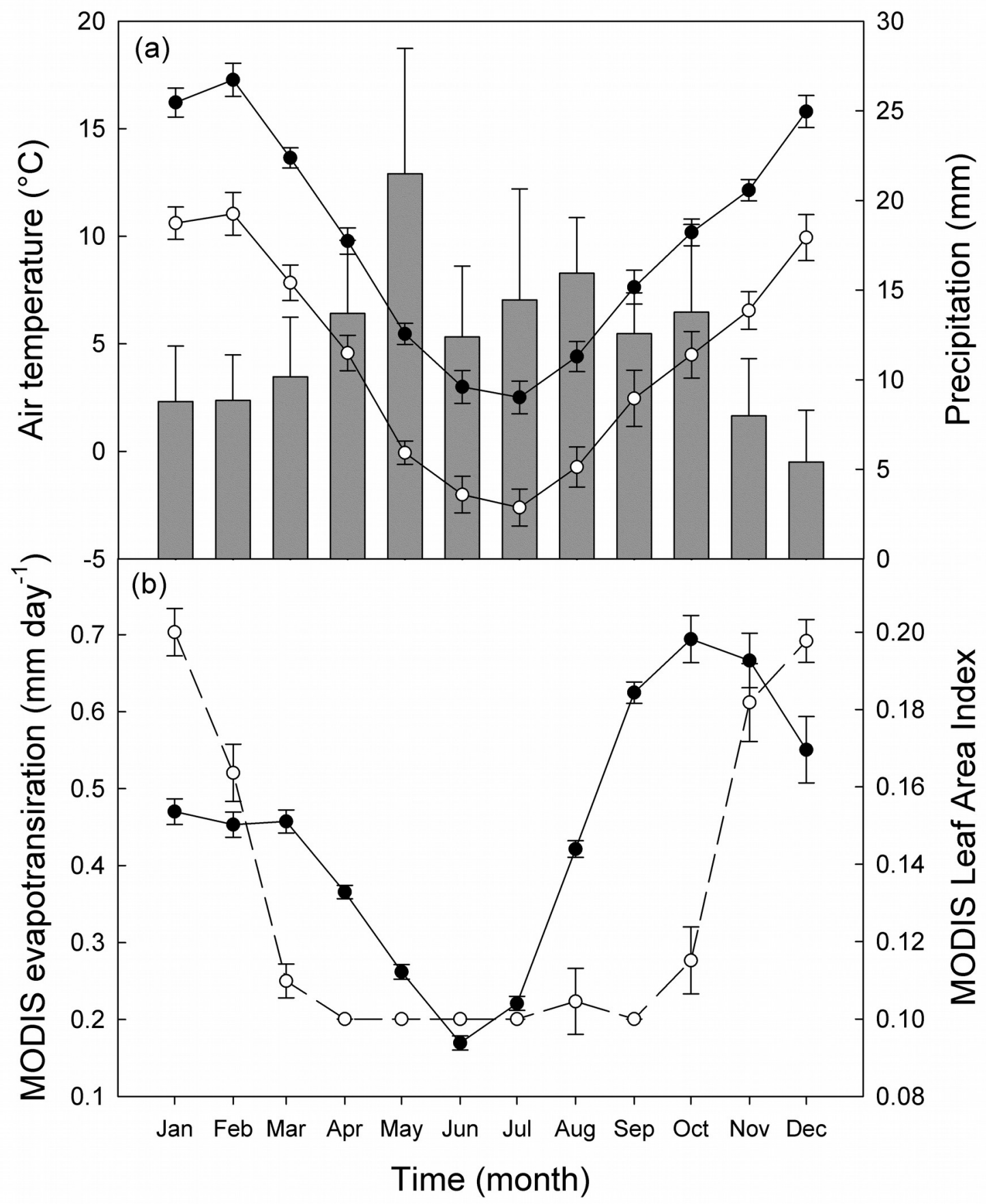

Figure 7: Monthly average values from 2001 to 2011 of (a) total monthly precipitation, minimum and mean air temperatures (open and filled symbols, respectively), (b) average daily MODIS evapotranspiration per month and MODIS leaf area index (filled and open symbols, respectively). Symbols are mean \pm SE. Bars are mean precipitation + SE. 


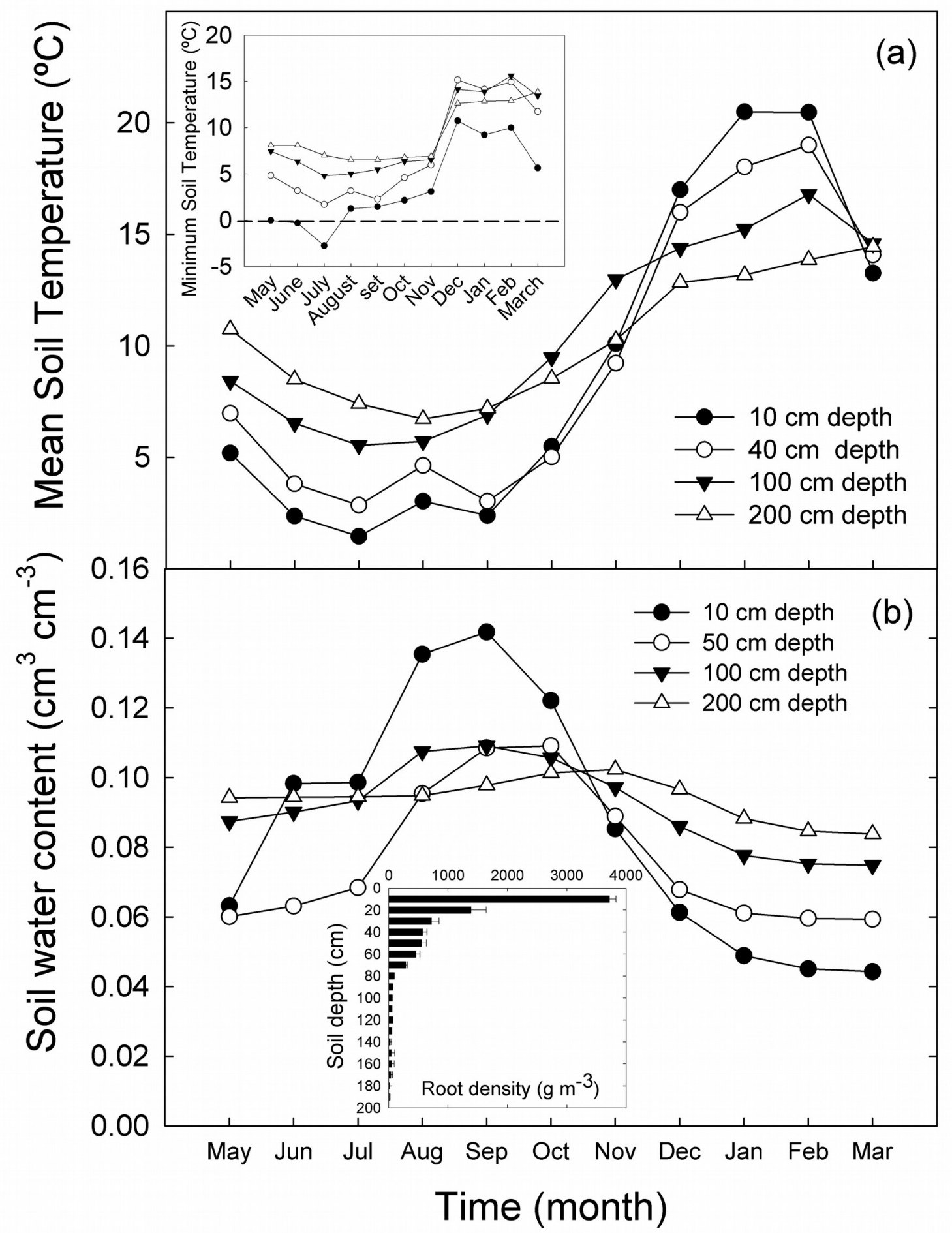

Figure 8: (a) Monthly average soil temperature at different depths (inset is minimum absolute daily soil temperature), (b) Soil water content at different depths (inset in panel b is the root density at different soil depths) from May 2010 to March 2011. 